\title{
ПОНЯТИЕ «ЗАГРЯЗНЕНИЕ МОРСКОЙ СРЕДЫ» В РОССИЙСКОМ И МЕЖДУНАРОДНОМ ПРАВЕ
}

\begin{abstract}
Аннотация. В статье рассматривается чрезвычайно важное для современного права понятие «загрязнение морской средыл", поскольку от его содержания во многом зависит уровень охрань Мирового Океана. Дается характеристика данного понятия как с точки зрения естественных наук, так и юриспруденции. Исследуются определения данного термина, используемые в международном и российском праве (международных конвенциях и федеральных законах Российской Федерации). Анализируются взгляды по данному вопросу отечественных и зарубежных специалистов: юристов, ученых-экологов. В процессе работы использовались общенаучные, частные и специильные методы познания, в их числе: логический, системно-структурный, сравнительно-правовой, метод анализа и синтеза, формально-юридический и др. В статье проведен с междисииплинарных позиций анализ понятия «загрязнение морской средыl», используемого в отечественном и международном праве, сделаны предложения по совершенствованию данного понятия. В особенности о необходимости расширения используемого в настоящее время определения рассматриваемого термина в части, касающейся видов и способов совершения «загрязнения морской среды».
\end{abstract}

Ключевые слова: морская среда, загрязнение, понятийный аппарат, охрана природы, мировой океан, загрязнитель, экология, сброс, захоронение, инвазия

Abstract: The article concerns the definition of "pollution of marine environment", which is extremely topical for the modern law, since the threshold of protection of the World ocean to a considerable extend depends on its elements. The author characterizes this term from the standpoints of natural sciences and jurisprudence. He studies definitions of this term in international and Russian law (including international treaties and Federal Laws of the Russian Federation). The author then analyzes the position of Russian and foreign legal scholars and environmental specialists on this issue. The author used general and specific scientific cognition methods, including logical, systemic and structural analysis, comparative legal studies, analysis and synthesis, formal legal approach, etc. The article includes an interdisciplinary study of the definition of "pollution of marine environment" in Russian and international law, and he provides propositions for its improvement, especially concerning widening the scope of this term in part of types and methods of committing "pollution of marine environment".

Keywords: marine environment, pollution, definition apparatus, environmental protection, the World ocean, pollution agent, environment, dump, disposal, invasion.

M ировой океан имеет исключительное значение в жизнеобеспечении Земли. Это и «легкие» Планеты, и сосредоточение огромных богатств полезных ископаемых, и биологические ресурсы. Сохранение морской среды должно являться одним из приоритетных направлений как международной, так и национальной политики. Очевидно, что понятие «загрязнение морской средыл» играет в этой связи первостепенную роль, от его содержания во многом зависит уровень охраны этого природного объекта.

Рассмотрение данного вопроса целесообразно начать с определений загрязнения, применяющихся в естественных науках. Одно из определений загряз- нения в экологии звучит как «неблагоприятное изменение нашего окружения, являющееся полностью или в основном побочным результатом деятельности человека» (Б. Небел, 1994). Под загрязнением также понимается внесение в ту или иную экологическую систему несвойственных ей живых и (или) неживых компонентов, физических или структурных изменений, прерывающих или нарушающих процессы круговорота и обмена веществ, потока энергии с непременным следствием в виде снижения продуктивности или разрушения этой экосистемы ${ }^{1}$.

\footnotetext{
${ }^{1}$ http://slovari.yandex.ru/dict/bezopasnost/article/bez/bez-0203. htm (28. 04. 2008).
} 
Французский ученый Ф. Рамад определял загрязнение как «неблагоприятное изменение окружающей среды, которое целиком или частично является результатом человеческой деятельности, прямо или косвенно меняет распределение приходящей энергии, уровни радиации, физико-химические свойства окружающей среды и условия существования живых существ»².

В словаре по естественным наукам приводится следующее определение загрязнения - привнесение в среду или возникновение в ней новых (нехарактерных для нее) физических, химических или биологических агентов, или превышение естественного среднемноголетнего уровня концентрации тех же агентов в рассматриваемый период

В науке различают следующие виды загрязнения окружающей среды: химическое (тяжелыми металлами, пестицидами, СПАВ, пластмассами и т.п.), физическое (тепловое, шумовое, радиоактивное, электромагнитное) и биологическое (биогенное, микробиологическое, чужеродными видами).

Особого внимания, на наш взгляд, заслуживает такой тип загрязнения, как загрязнение чужеродными видами. Оно сложно контролируется и представляет огромную угрозу как для морской среды, так и для сохранения биоразнообразия в целом.

В настоящее время в результате антропогенной деятельности ежедневно перемещаются десятки тысяч видов животных и растительных организмов, причем значительное число успешных интродукций чужеродных видов приводит к серьезнейшим экологическим, социальным и экономическим последствиям. Чужеродные (инвазивные) виды считаются второй по значению угрозой биоразнообразию (после разрушения мест обитания). Вселение чужеродных видов животных, растений и микроорганизмов в природные сообщества в результате деятельности человека (интродукции) представляет собой один из типов «биологического загрязнения». Последствия биологического загрязнения, в отличие от других видов антропогенного воздействия, имеют, как правило, необратимый характер, что обусловливает особую опасность

${ }^{2}$ Передельский Л.В. Экология: Учебник. М.: Проспект, 2008. C. 231.

${ }^{3} \mathrm{http}: / /$ slovari.yandex.ru/dict/gl_natural/article/121/121_565. HTM (28. 04. 2008). этого вида антропогенного воздействия. Одним из наиболее ярких примеров катастрофических биологических инвазий является сравнительно недавнее занесение с балластными водами судов американского гребневика мнемиопсиса в Черное и Каспийское моря ${ }^{4}$.

Однако, говоря о загрязнении чужеродными видами, следует помнить о том, что большая часть таких случаев происходит, хотя и благодаря деятельности людей, но без их контроля, что отмечают и западные ученые, занимающиеся данной проблематикой. Следовательно, большая часть подобного загрязнения происходит невиновно (суда неизбежно перевозят огромное число живых организмов в балластных водах, которые закачиваются в балластные отсеки для выравнивания ватерлинии, компенсации грузов; эти отсеки могут содержать тысячи тонн воды, а организмы, содержащиеся в этой воде, могут быть перенесены и выпущены в результате сброса воды в другой окружающей среде и стать в ней захватчиками, выживая коренные виды и причиняя существенные изменения окружающей среде), в результате чего невозможно применение ответственности, либо установление виновных невозможно из-за того, что последствия такого вида загрязнения проявляются не сразу, в отличие, например, от загрязнения химическими веществами.

Для сокращения числа чужеродных видов, перевозимых в балластных водах (а также болезнетворных микробов), по мнению профессора Фреда Доббса (Fred Dobbs (Old Dominion University)), возможно применение широкого ряда методов: от фильтрации до использования биоцидов - веществ, способных уничтожать или повреждать живые организмы, от ультразвука

\footnotetext{
${ }^{4}$ См: Алимов А.Ф., Панов В.Е., Крылов П.И., Телеш В.И., Быченков Д.Е., Зимин В.Л., Максимов А.А., Филатова Л.А. Проблема антропогенного вселения чужеродных организмов в водоемы бассейна Финского залива // Экологическая обстановка в Санкт-Петербурге и Ленинградской области в 1997 году. Справочно-аналитический обзор. СПб., 1998. С. 243-249; Каспийская экологическая программа, 2002. http://caspianenvironment.org (15.07.2007); Baltic SeaA lien Species Database, 2001. http://www.ku.lt/nemo/mainnemo.htm (15.07.2007); Панов В.E. Биологическое загрязнение как глобальная экологическая проблема: международное законодательство и сотрудничество. http://www.zin.ru/projects/ invasions/rus/rtable 1.htm (15.07.2007); и др.
} 
до облучения ультрафиолетом ${ }^{5}$. Закрепление подобных мер на уровне Международной Морской Организации могло бы увеличить эффективность борьбы с инвазиями, а также обеспечить возможность применения ответственности за нарушение данных стандартов.

Федеральный закон от 10 января 2002 г. № 7-Ф3 «Об охране окружающей среды» ${ }^{6}$ определяет загрязнение окружающей среды как поступление в окружающую среду вещества и (или) энергии, свойства, местоположение или количество которых оказывают негативное воздействие на окружающую среду (т.е. наносит экологический вред). Из этого определения следует, что российский законодатель понимает под загрязнением процесс, приводящий к негативным последствиям (к изменениям свойств окружающей среды), а не процесс, который создает угрозу наступления таких последствий.

Определения же загрязнения в международном праве несколько отличаются от понятия, принятого в Российской Федерации. Например, в соответствии с Конвенцией по морскому праву $(1982)^{7}$ под загрязнением морской среды понимается привнесение человеком, прямо или косвенно, веществ или энергии в морскую среду, включая эстуарии, которое приводит или может привести к таким пагубным последствиям, как вред живым ресурсам и жизни в море, опасность для здоровья человека, создание помех для деятельности на море, в том числе для рыболовства и других правомерных видов использования моря, снижение качества используемой морской воды и ухудшение условий отдыха. Другие международные конвенции, посвященные охране морской среды, в целом используют аналогичный подход к загрязнению морской среды или загрязнителям; в них учитывается не только наступивший вред, но и возможность его наступления.

Конвенция по защите природной морской среды района Балтийского моря (1992) ${ }^{8}$ дает определение

\footnotetext{
${ }^{5}$ http://www.sciencedaily.com/releases/2008/05/080528191422. htm (25.08. 2009).

${ }^{6}$ СЗ РФ. 2002. № 2. СТ. 133.

${ }^{7}$ СЗ РФ. 1997. № 48. Ст. 5493.

${ }^{8}$ Сборник рекомендаций Хельсинкской комиссии. Справочнометодическое пособие. СПб.: РОО Экология и Бизнес, 2001. С. 19-66.
}

загрязнению морской среды с суши (от наземных источников) под которым понимается загрязнение моря сбросами с суши от всех видов точечных или рассредоточенных источников, поступающими в море водным или воздушным путем, либо непосредственно с побережья. Оно включает также загрязнение в результате любого преднамеренного удаления с суши на морское дно посредством тоннеля, трубопровода или другим путем.

В статье 252 УК РФ, предусматривающей ответственность за загрязнение морской сре$\partial b l$, данное явление описано крайне сжато и не раскрыто полностью: в случае загрязнения из находящихся на суше источников законодатель не указывает конкретные способы совершения данного вида деяния, следовательно, оно может быть совершено любыми способами и включать все виды загрязнения. Однако в случае загрязнения морской среды из источников, находящихся непосредственно в морской среде, либо над ней, законодатель раскрывает признаки деяния путем описания способов его совершения, указывая при этом сброс и захоронение веществ и материалов (с нарушением правил), таким образом, исключая некоторые виды загрязнения, например энергией.

В соответствии с Конвенцией по морскому праву (1982) ${ }^{9}$ под захоронением понимается: а) любое преднамеренное удаление отходов или других материалов с судов, летательных аппаратов, платформ или других искусственно сооруженных в море конструкций; б) любое преднамеренное уничтожение судов, летательных аппаратов, платформ или других искусственно сооруженных в море конструкций.

При этом «захоронением» не считается: а) удаление отходов или других материалов, присущих или являющихся результатом нормальной эксплуатации судов, летательных аппаратов, платформ или других искусственно сооруженных в море конструкций и их оборудования, кроме отходов или других материалов, транспортируемых судами, летательными аппаратами, платформами или другими искусственно сооруженными в море конструкциями, которые эксплуатируются в целях удаления таких материалов, или подвозимых к таким судам, летательным аппаратам, платформам или другим искусственно сооружае-

\footnotetext{
${ }^{9}$ СЗ РФ. 1997. № 48. Ст. 5493.
} 
мым в море конструкциям, а также кроме тех, что являются результатом обработки таких отходов или других материалов на таких судах, летательных аппаратах, платформах или конструкциях; б) помещение материалов для целей иных, чем их простое удаление, при условии, что это не противоречит целям Конвенции.

Конвенция по предотвращению загрязнения моря сбросами отходов и других материалов $(1972)^{10}$ определяет сброс как любое преднамеренное удаление в море отходов или других материалов с судов, самолетов, платформ или других искусственно сооруженных в море конструкций; любое преднамеренное захоронение в море судов, самолетов, платформ или других искусственно сооруженных в море конструкций.

Иными словами, в данном определении понятия «захоронение» и «сброс» соотносятся как часть и целое, но понятие «захоронение» применяется только в отношении затопления в море судов, самолетов, платформ или других искусственных сооружений, т.е. не материалов или каких-либо веществ, а технических объектов.

Международная конвенция по предотвращению загрязнения моря нефтью (Лондон, 12 мая 1954 г.) применяет термин «слив», который по отношению к нефти или нефтяной смеси означает любой слив или утечку, независимо от того, чем оно вызвано.

Анализ данных (конвенционных) понятий показывает, что определение сброса и захоронения являются либо идентичными, либо взаимопоглощающими.

В российском законодательстве данные понятия достаточно четко определены и разделены, их разъяснение дается в ч. 1 ст. 37 Федерального закона от 31 июля 1998 г. № 155-Ф3 «О внутренних морских водах, территориальном море и прилежащей зоне Российской Федерации» ${ }^{11}$. Под термином «захоронение» понимается преднамеренное удаление отходов или других материалов. Вредные вещества захоронению не подлежат. К ним применяется термин «сброс». Сброс вредных веществ или стоков, содержащих такие вещества,

\footnotetext{
${ }^{10}$ Сборник действующих договоров, соглашений и конвенций, заключенных СССР с иностранными государствами. Вып. XXXII. М.: Международные отношения, 1978. С. 540-549.

${ }^{11}$ СЗ РФ. 1998. № 31. Ст. 3833.
}

означает любой сброс с судов и иных плавучих средств, летательных аппаратов, искусственных островов, установок и сооружений, какими бы причинами он ни вызывался, включая любые утечку, удаление, разлив, протечку, откачку, выделение или опорожнение. Сброс вредных веществ не включает выброс вредных веществ, происходящий непосредственно вследствие разведки, разработки и связанных с ними процессов обработки в море минеральных ресурсов внутренних морских вод и территориального моря, а также сброс вредных веществ для проведения правомерных морских научных исследований в целях борьбы с загрязнением или контроля над ним.

Следует отметить, что положения ст. 37 указанного Закона не распространяются на объекты, расположенные на берегу, а касаются лишь объектов, место нахождения которых - морская среда.

В учебниках по уголовному праву и комментариях к УК РФ понятие «загрязнения морской среды» раскрывается как привнесение в морскую среду веществ и материалов, ухудшающих качество морской среды, ограничивающих ее использование, приводящее к уничтожению, сокращению, истощению или заболеваниям живых ресурсов моря ${ }^{12}$. К понятию «загрязнение» подходят как к процессу, имеющему негативные последствия в виде изменения качества морской среды, либо понятие «загрязнения морской» среды определяется с помощью описания некоторых способов его совершения ${ }^{13}$, что является недостаточным для раскрытия такого сложного понятия.

На наш взгляд, наиболее емкое и полное определение термина «загрязнение морской среды»» дано в Конвенции по морскому праву (1982) ${ }^{14}$, так как в нем оно рассматривается не только как

\footnotetext{
12 Уголовное право России. Особенная часть: Учебник / Под ред. В.Н. Кудрявцева, В.В. Лунеева, А.В. Наумова. 2-е изд., перераб и доп. С. 359.

${ }^{13}$ См., например: Комментарий к Уголовному кодексу РФ / Отв. ред. А.В. Наумов. М.: Юристь, 2004. С. 640;

Комментарий к Уголовному кодексу РФ / Под ред. А.И. Рарога. М.: Проспект, 2008. С. 470.

Уголовное право. Общая и особенная части: Учебник для вузов / Под ред. Н.Г. Кадникова. М.: Городец, С. 681; Ветров Н.И. Уголовное право. Особенная часть: Учебник для вузов. М.: ЮНИТИ-ДАНА; Закон и право, 2000. С. 331; Уголовное право России. Практический курс / Под ред. А.И. Бастрыкина, А.В. Наумова. М.: Волтерс Клувер, 2007. С. 606.

${ }^{14}$ СЗ РФ. 1997. № 48. Ст. 5493.
} 
процесс, приводящий к негативным изменениям морской среды, но и как процесс, который создает угрозу наступления таких последствий.

Однако заметим, что понятия «загрязнения», предложенные учеными-экологами, значительно более емкие и описывают больше видов загрязнения, чем понятия, используемые правоведами.

По нашему мнению, для более полной защиты морской среды необходимо, чтобы понятие загрязнения включало все виды и способы, которыми оно может быть совершено, а не только самые распространенные, так как интенсивность освоения и использования морской среды растет и будет продолжать расти, поскольку увеличивающиеся быстрыми темпами население Земли все больше будет нуждаться в Океане как источнике минеральных и биологических богатств, альтернативной энергии, как транспортной системе, связывающей собой все части света. Таким образом, в недалеком будущем те виды и способы загрязнения морской среды, которые в настоящий момент еще не являются основными, могут развиться до угрожающих масштабов.

\section{Библиография:}

1. Алимов А.Ф., Панов В.Е., Крылов П.И., Телеш В.И., Быченков Д.Е., Зимин В.Л., Максимов А.А., Филатова Л.А. Проблема антропогенного вселения чужеродных организмов в водоемы бассейна Финского залива // Экологическая обстановка в Санкт-Петербурге и Ленинградской области в 1997 году. Справочно-аналитический обзор. СПб., 1998. С. 243-249;

2. Ветров Н.И. Уголовное право. Особенная часть: Учебник для вузов. М.: ЮНИТИ-ДАНА; Закон и право, 2000.

3. Наумов А.В. Комментарий к Уголовному кодексу РФ / Отв. ред. А.В. Наумов. М.: Юристъ, 2004.

4. Рарог А.И. Комментарий к Уголовному кодексу РФ / Под ред. А.И. Рарога. М.: Проспект, 2008.

5. Передельский Л.В. Экология: Учебник. М.: Проспект, 2008.

6. Кадников Н.Г. Уголовное право. Общая и особенная части: Учебник для вузов / Под ред. Н.Г. Кадникова. М.: Городец, 2006 г.

7. Панов В.Е. Биологическое загрязнение как глобальная экологическая проблема: международное законодательство и сотрудничество. http://www.zin.ru/projects/invasions/rus/rtable_1.htm (15.07.2007).

\section{References (transliteration):}

1. Alimov A.F., Panov V.E., Krylov P.I., Telesh V.I., Bychenkov D.E., Zimin V.L., Maksimov A.A., Filatova L.A. Problema antropogennogo vseleniya chuzherodnykh organizmov v vodoemy basseina Finskogo zaliva // Ekologicheskaya obstanovka v Sankt-Peterburge i Leningradskoi oblasti v 1997 godu. Spravochnoanaliticheskii obzor. SPb., 1998. S. 243-249;

2. Vetrov N.I. Ugolovnoe pravo. Osobennaya chast': Uchebnik dlya vuzov. M.: YuNITI-DANA; Zakon i pravo, 2000.

3. Naumov A.V. Kommentarii k Ugolovnomu kodeksu RF / Otv. red. A.V. Naumov. M.: Yurist", 2004.

4. Rarog A.I. Kommentarii k Ugolovnomu kodeksu RF / Pod red. A.I. Raroga. M.: Prospekt, 2008.

5. Peredel'skii L.V. Ekologiya: Uchebnik. M.: Prospekt, 2008.

6. Kadnikov N.G. Ugolovnoe pravo. Obshchaya i osobennaya chasti: Uchebnik dlya vuzov / Pod red. N.G. Kadnikova. M.: Gorodets, 2006 g.

7. Panov V.E. Biologicheskoe zagryaznenie kak global'naya ekologicheskaya problema: mezhdunarodnoe zakonodatel'stvo i sotrudnichestvo. http://www.zin.ru/projects/invasions/rus/rtable_1.htm (15.07.2007). 